\section{Modern museums}

Creating Connections: Museums and the Public Understanding of Research

edited by David Chittenden, Graham

Farmelo \& Bruce V. Lewenstein

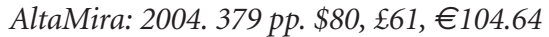

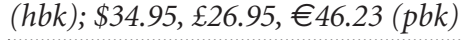

\section{David A. Micklos}

In the nineteenth century, science museums evolved from being aristocrats' private 'cabinets of curiosities' to public vehicles for the exposition of science. They continued to develop during the twentieth century alongside the logical positivist view of science, which holds that the experimental world is connected to the real world through a complex set of rules. Because of this direct correspondence, experiments could, in effect, uncover truth. So science museums presented the public with the validated artefacts of science, and public education systems fed their students received facts that could, in theory, be learned by rote memorization.

During the second half of the twentieth century, the logical positivist conception gave way to down-to-earth 'use' theories, which emphasize the creative and problemsolving aspects of science. This led, especially in the United States, to increased emphasis on hands-on experience with the process of science. A new breed of science centre was developed, focusing on demonstrations of scientific principles and manipulative models. By the end of the century, these centres faced competition from music videos and virtual reality. Despite their best attempts to make science more appealing, science museums and centres have suffered declining attendance, and polls show only modest gains in the public's knowledge of science. Science museums and centres are responding by experimenting with ways to connect the public to scientific endeavour.

The set of essays in Creating Connections focuses on the movement dubbed 'public understanding of research' (PUR). One can discern three themes that shaped discussions at a 2002 conference of museum and media people from which this book emanated: an approach based on current, unfinished 'science in the making'; public involvement and dialogue; and the process through which scientists make sense of the world.

The two major public science museums in London illustrate polar reactions to the PUR mandate. Graham Farmelo explains that the Science Museum has grafted new appendages for public engagement to its admittedly stodgy collections. Its Wellcome Wing uses state-of-the-art computer and graphical presentations, and the Dana Centre is a multimedia-wired pub designed to draw young adults into science discussion.

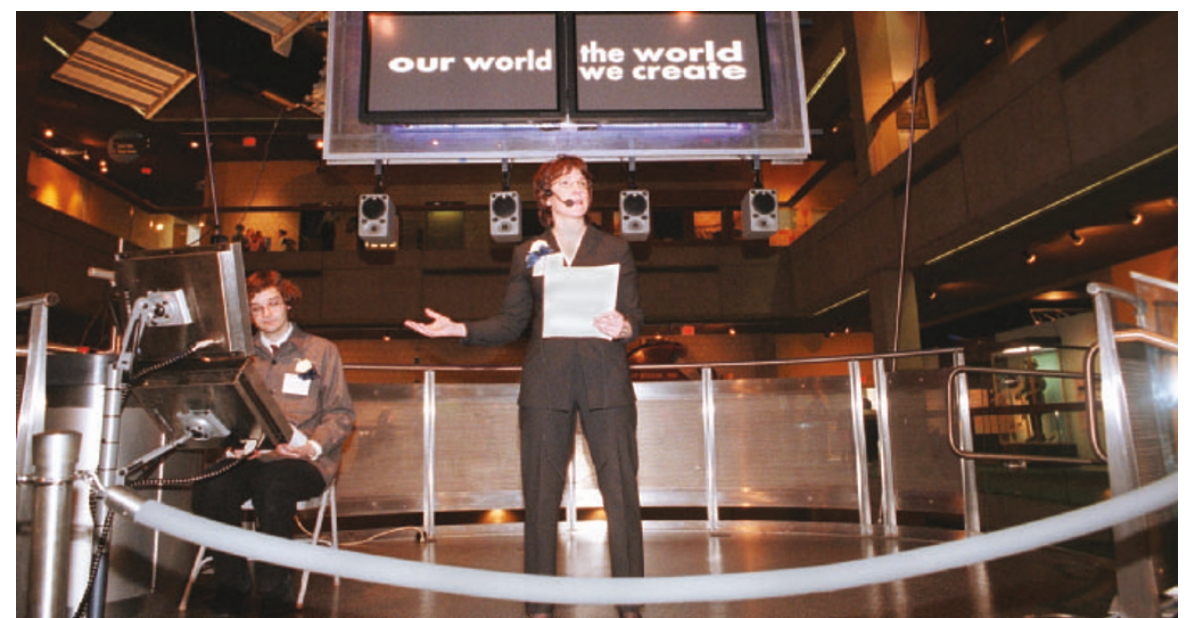

Breaking news: Boston's Current Science \& Technology Center interprets stories as they happen.

On the other hand, the Natural History Museum has turned itself inside out with its Darwin Centre, creating a public interface with the guts of its research collection, as Neil Chalmers explains.

The drier parts of natural-history museums worked in their time (and sometimes still do), because in wandering their halls one can feel connected to the explorer who happened upon the strange and wonderful items on display. By comparison, most science centres today are disconnected from the science they attempt to explain. The hands-on manipulatives that are their raison d'être are often too abstracted to provide any sense of personal connection. As Christine CansfieldSmith explains, the Discovery Science Centre attempts to foster closer interactions with scientists by locating itself on a research campus of Australia's Commonwealth Scientific and Industrial Research Organization. The US National Science Foundation is also attempting to forge direct connections by providing educational outreach funds as a condition of major research projects.

A highlight of the book is Carol Lynn Alpert's engaging description of how the Museum of Science in Boston developed its Current Science \& Technology Center. One cannot fail to be impressed by her story of how seven full-time staff have laboured to weave mini-exhibits, theatre, interviews with scientists, and Internet multimedia into their daily audience discussions of breaking news.

Allied to this news emphasis are 'science cafés' and other devices to engage the public in dialogue about the impact of science on society. Unfortunately, I fear that the desire for public conciliation has become so rampant in Europe that it has turned many otherwise gifted science communicators into apologists for science. Opinion polls show that although the public in the United States and Europe hold scientists in almost equal esteem, Europeans are much more distrustful of the scientific enterprise.

Favouring rhetoric over process might have serious consequences. For example, genetically modified (GM) foods are widely banned in Europe, where, doubtless, few people understand the process through which a GM plant is produced. In contrast, hands-on experiments with gene transfer in bacteria have been common in US high schools since the mid-1980s, presumably providing students with some real insight into the GM debate. Despite nearly two decades of safe practice in the United States, simple gene-transfer experiments are still absent from most European schools.

A growing emphasis on standardized testing threatens to erase such gains in hands-on instruction, however, and push US science education back towards the realm of received facts. Although the US National Science Education Standards include process, historical and societal elements, these take a back seat to more easily measured content. Experiments are, after all, never a time-efficient means of memorizing scientific facts.

Sadly, this volume is largely mute on the issues and opportunities raised by standardized testing, despite the fact that school students are a large constituency of every science museum or centre. There is a market for the type of high-quality experiments that schools lack the time or facilities to conduct, although few science museums have invested in teaching labs. At my own institution, we have found that teaching labs can easily generate enough income to pay for the faculty and supplies needed to run them.

I agree with Rick Bonney and Don Pohlman, who say in the book that science museums can best aid formal science education by providing insight into the process of science, which may be missed in fact-driven classrooms. Perhaps it is time for science museums and centres to focus on providing semi-structured environments in which students can connect with the experiments that really drive science.

David A. Micklos is at the Dolan DNA Learning Center, Cold Spring Harbor Laboratory, 1 Bungtown Road, Cold Spring Harbor, New York 11724, USA. 